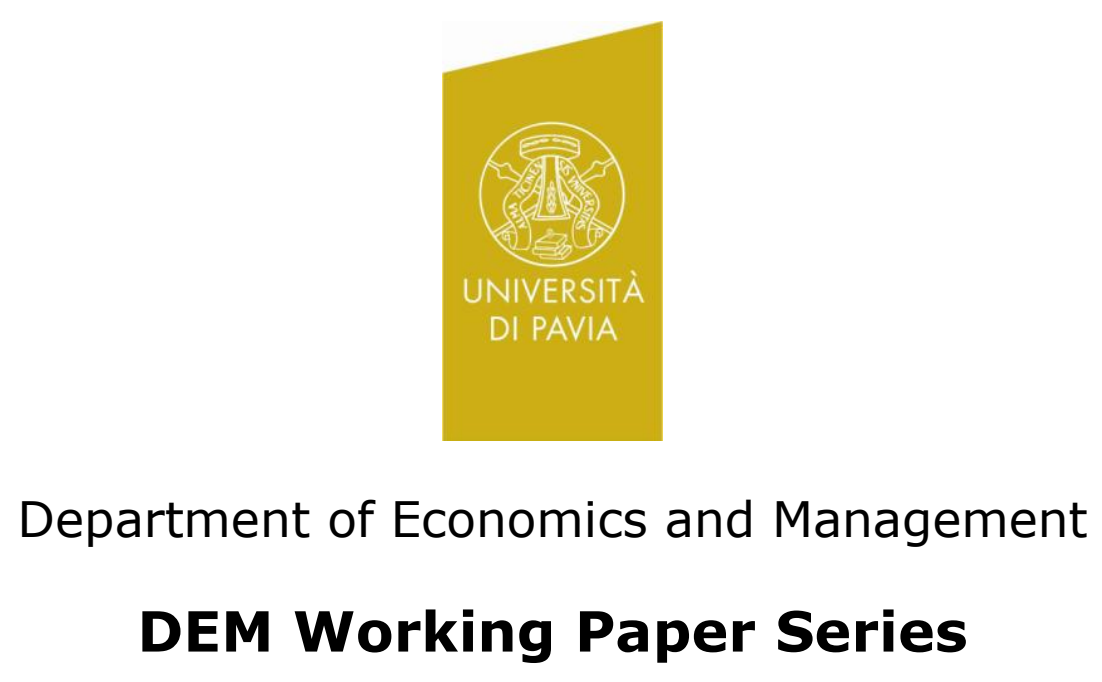

The price and income elasticities of the top clothing exporters: Evidence from a panel data analysis

\author{
Donatella Baiardi \\ (Università di Milano-Bicocca) \\ Carluccio Bianchi \\ (Università di Pavia) \\ Eleonora Lorenzini \\ (Università di Pavia)
}

\author{
\# 74 (03-14) \\ Via San Felice, 5 \\ I-27100 Pavia \\ http://epmq.unipv.eu/site/home.html
}




\title{
THE PRICE AND INCOME ELASTICITIES OF THE TOP CLOTHING EXPORTERS: EVIDENCE FROM A PANEL DATA ANALYSIS
}

\begin{abstract}
This paper studies the main export function features of twelve top clothing exporters (China, Hong Kong, France, Germany, India, Indonesia, Italy, Netherlands, Spain, Turkey, UK and USA) in the period between 1992 and 2011. Price and income elasticities are estimated for each country using a panel data approach, after controlling for nonstationarity, cointegration and Granger causality. Rolling regressions are also performed, and show the existence of elasticities instability over time. The analysis suggests that most advanced countries, including Hong Kong, changed their position in the clothing global value chain towards an "organisational" role. China confirms its leadership in clothing exports although its rising price elasticity sounds a warning with regard to future prospects.
\end{abstract}

JEL: F14, C23, L67

Keywords: Clothing exports, Price and income elasticities, Parameter stability, Panel data analysis

\section{HIGHLIGHTS}

- We study the main export function features of 12 top clothing exporters

- 12 panel datasets of 37 goods each are built and analyzed over the period 1992-2011

- Rolling regressions show elasticities instability over time

- Hong Kong and most advanced countries have become organizational hubs

- China confirms its leading position but with a strong increase in price elasticity 


\section{Introduction}

The analysis of the size and time stability of a country's export elasticities is of central importance in empirical trade studies (see, among others, Arize, 2001; Aziz \& Li, 2008; Hooper et al., 2000; Sharma, 2001, and Thorbecke, 2010), given their fundamental role in terms of growth performance, international competitiveness, balance of payments equilibrium and industrial policy decisions. In fact, as noted by Aziz and Li (2008), if export price and income elasticities are low, changes in external conditions or in the exchange rate are unlikely to have much impact on a country's growth or its current account dynamics. However, if they are not stable, little can be said about how an economy might respond to such changes. In the empirical trade literature, several papers focusing on Asian countries study the size and stability of export function parameters for the whole economy (Arize, 1990, 2001; Aziz \& Li, 2008; Lucas, 1988; Muscatelli et al., 1992;). The most widely studied case is China, given its increasing importance in international trade especially after its entry into the World Trade Organization. In particular, Yao et al. (2013) estimate China's export elasticities for the time period 1992-2006 and find that its outstanding performance is due to the joint influence of a very high income elasticity (2.34) and a surprisingly low price elasticity (-0.65). However, Aziz and Li (2008) find that in the same period price and income elasticities were not stable, but increased over time, because of changes in the composition and degree of sophistication of exports.

All above mentioned studies use aggregate data and real effective exchange rates (REERs) to estimate the basic parameters of the export functions. Some studies highlight the importance of using disaggregated sectoral data in order to obtain specific trade elasticities at the industry level, but still adopt aggregate REER indexes in their estimations. Finally, others make use of industry-specific REERs (Dai \& Xu, 2013): this approach is the most appropriate from both a theoretical and an econometric standpoint, as confirmed by the fact that a significant relationship between sectoral exchange rates and exports can be identified (Dai \& Xu, 2013), contrary to many studies using aggregate REERs.

Sectoral elasticities have the further advantage of allowing comparisons between different countries in specific industrial sectors, in order to shed light on their positioning in the global competition and avoid problems connected to the composition fallacy (for details, see Mayer, 2003). Price elasticities can thus indicate the relative strength of a country's production, since it is likely that high-quality goods will exhibit an inelastic foreign demand and vice versa. On the other hand, income elasticities, closely correlated with the export growth rate, reflect the non-price competitiveness of a country, and are influenced by factors like export composition by goods and destination markets, embodied technology, marketing strategies and promotion, distribution services, financial assistance to exporters, and so on.

The aim of this paper is to estimate the export price and income elasticities for the world's top exporting countries in the clothing industry. This sector is chosen since it has been the driver of the impressive export performance of many Asian countries, including China, Hong Kong, Bangladesh, India, Vietnam and Indonesia. This is particularly true for China, the leading exporter in 2011 with a $37.3 \%$ share of world exports (see Table 1). ${ }^{1}$ Clothing is also a low-tech industry which still plays an

\footnotetext{
${ }^{1}$ For more details, see Section 2.
} 
important role in value added creation and trade in many advanced countries, ${ }^{2}$ despite recent strong competition from lower-wage economies. Finally, clothing also carries the quality reputation of a country and its productive system.

The contribution of this paper is threefold. First, price and income elasticities for the top exporting countries in the last twenty years are estimated and compared. Second, these elasticities are re-estimated for different sub-periods in order to verify whether they are stable over time. Third, our econometric analysis is used to provide insights about strengths, weaknesses and prospects for the clothing industry in the countries studied.

Following an original methodology, we use an appropriate measure of relative prices, obtained as the ratio between each country's disaggregated export unit values and the average unit values (AUVs) of the whole sample. We also examine issues that have been little investigated in the literature, such as the order of integration of trade variables, their possible cointegration in the long run and the direction of Granger causality between them. Our empirical analysis uses a panel data approach, which allows us to use disaggregated AUVs and obtain better results in the study of causality with respect to time series, as demonstrated in many empirical papers (see, among others, Hsiao \& Hsiao, 2006). The main findings of our study are the following. The variables of interest are cointegrated and causality is bidirectional with regard to exports and relative prices but unidirectional from world income towards export volumes. Income elasticities are very high (around 3) for China and Spain, and above 1 for India, Turkey, Indonesia, Germany and slightly France, so that their clothing exports growth rate is higher than the growth rate in world income. Price elasticities are similar across countries when estimated over the 20-year period; but rolling-period regressions show that they are not stable in time but increase substantially in the most recent time-spans for the biggest Asian exporters (China, India and Hong Kong).

The rest of the paper is structured as follows. Section 2 describes the data and the model specification. Section 3 presents the testing framework, which includes unit roots, cointegration tests and panel Granger-causality analysis. Section 4 reports the estimated long-run price and income elasticities of the countries considered, and proposes a stability analysis of these elasticities. Section 5 discusses the main findings and concludes with some hints to policy implications.

\section{Model Specification and Data}

Our analysis initially considered the disaggregated clothing export data for the top fifteen countries (Bangladesh, Belgium, China, Hong Kong, France, Germany, India, Indonesia, Italy, Netherlands, Spain, Turkey, UK, USA and Vietnam) in the period between 1992 and 2011. These countries together account for $82.4 \%$ of the total value of clothing world exports in 2011 (See Table 1).

Table 1 about here

\footnotetext{
${ }^{2}$ See Table A1 in the Appendix for the share of clothing in total manufacturing exports for the twelve countries considered in the subsequent analysis.
} 
The data, retrieved from the UN Comtrade database, are disaggregated at the 4 digit level of the Standard International Trade Classification (Rev. 3), which implies the consideration of 37 distinct goods. ${ }^{3}$

Three countries however (Bangladesh, Belgium and Vietnam) were excluded from the sample because of incomplete records in the period considered. Our final analysis is then carried out on the twelve remaining countries (China, Hong Kong, France, Germany, India, Indonesia, Italy, Netherlands, Spain, Turkey, UK, USA) accounting for $72.2 \%$ of world clothing exports in 2011. The available data are organized to form 12 panel datasets, one for each country. Each dataset then consists of 740 observations relative to 37 goods at the 4 digit level in the 20 -year time period considered.

\section{Table 2 about here}

Table 2 reports for each country the descriptive statistics for the variables of interest: export volumes, market shares and average unit values (AUVs), at the beginning and at the end of the time span considered, together with their average value in the whole period. ${ }^{4,5}$ Export volumes increase in all countries with the exception of Hong Kong and the USA. Export market shares decrease in most countries (France, Hong Kong, Indonesia, Italy, Netherlands, UK and USA), with a pronounced fall for Hong Kong, Italy and the USA. Spain, but mostly China, instead, record a substantial increase in their market shares; indeed it is worth noting that China after 2005 overcomes the threshold of $50 \%$ of total exports in volumes, more than doubling its 1992 share. $^{6}$ France, Indonesia and the Netherlands show a rather stable pattern. Quite interestingly, the share of Italy in value (USD) remains relatively high throughout the whole period, despite the poor quantity performance, thanks to the high increase in AUVs; moreover Italian AUVs are considerably higher than those of all other countries in the sample, especially in the most recent years.

For every country we estimate a panel data export function, specified as follows:

$$
\ln X_{i t}=\alpha_{i}+\beta_{1 i} \ln R P_{i t}+\gamma_{1 i} \ln G D P W_{t}+\varepsilon_{i t}
$$

where $i$ and $t$ refer to the $i$-th good and the $t$-th year respectively, with $i=1, \ldots, N$ and $t=1, \ldots, T . X_{i t}$ is the yearly export volume for each of the 37 goods; $R P_{i t}$ is the yearly relative export price of each good; GDPW $W_{t}$ is the annual world GDP in constant 2005 USD, which is invariant for each cross-section. ${ }^{7}$ An innovative feature of our estimation

\footnotetext{
${ }^{3}$ The list of these goods is reported in Table A2 in the Appendix.

${ }^{4}$ Hereafter, export market shares indicate the ratios between the export volume of each country and the total export volume of the 12 countries considered in the analysis.

${ }^{5}$ The export unit values for each good and country are computed by dividing exports values by their volumes. Similarly, average export unit values for each good of the whole sample countries are obtained by dividing total export values of each good by their total volumes.

${ }^{6}$ It should be noticed that in 1995 the General Agreement on Tariffs and Trade (GATT) Uruguay Round came into effect, so that it was decided to bring the textile and clothing sectors under the jurisdiction of the World Trade Organisation (WTO). The Agreement on Textile and Clothing (ATC) provided for the gradual dismantling of the quotas that existed under the Multi Fibre Arrangement (MFA), signed in 1974. The process ended in 2005.

${ }^{7}$ We depart from previous literature in that we do not study the export elasticities of any country with respect to specific destination markets but rather the elasticities of the top clothing exporters with respect to the whole world. This is because we are interested in comparing not the differences in the export
} 
is that the relative price is obtained as the ratio between the export unit value of each selected country for every good $i$ at time $t$ and the average export unit value of all countries considered for the same good and time. We believe that this measure corresponds to the actual price much more precisely that usually employed aggregate measures such as CPI-based REERs etc. All variables are transformed into natural logarithms and labelled $\ln X_{i t}, \ln R P_{i t}$ and $\ln G D P W_{t}$. The coefficients $\beta_{1 i}$ and $\gamma_{1 i}$ are the clothing export price and income elasticities, respectively. The former ones are expected to be negative, while the latter ones positive. The $\alpha_{i}$ are the intercepts for each good and the $\varepsilon_{i t}$ the error terms.

\section{A causality analysis between export volumes, relative prices and world income}

\subsection{Panel unit root tests}

As a first step, it is necessary to check whether each variable of interest is stationary. For this purpose, it is common practice in the literature to perform many panel unit root tests, given the shortcomings of any single test with regard to sample size and power properties. Hence we propose three different panel unit root tests: the Breitung (2000) and the Hadri (2000) test, which assume homogeneity among each cross section, and a more recent test developed by Pesaran (2007). The null hypothesis of these unit root tests is that all series contain a unit root, with the exception of the Hadri test, whose null hypothesis is that all panels are stationary. The Hadri unit root test is performed to confirm or reject any conclusion based on the null hypothesis of nonstationarity. Moreover, the Pesaran unit root test is more powerful because it takes into account the possible presence of cross-sectional dependence in heterogeneous panels. As underlined by Pesaran (2007), this test is appropriate even in the case of very small sample sizes (i.e., when $N$ and $T$ are equal to 10). Finally, two popular time series unit root tests are employed to assess the order of integration of $G D P W_{t}$ : the Augmented Dickey-Fuller (ADF) and the Kwiatkowski-Phillips-Schmidt-Shin (KPSS) tests (Said and Dickey, 1984 and Kwiatkowski et al., 1992, respectively). This choice is motivated by the nature of this variable, which is a time series, invariant for each cross-section.

\section{Tables $3 \mathrm{a}, 3 \mathrm{~b}$ and $3 \mathrm{c}$ about here}

Tables $3 \mathrm{a}, 3 \mathrm{~b}$ and $3 \mathrm{c}$ show the results of the above specified unit root tests. Export volumes $\left(\ln X_{i t}\right)$ are found to be $\mathrm{I}(1)$ for all countries, with the UK as the only exception in the case of the Breitung test, which rejects the null hypothesis of nostationarity. As regards relative prices $\left(\ln R P_{i t}\right)$ the Breitung test suggests stationarity for all countries with the only exception of China and Indonesia. ${ }^{8}$ However, both the Hadri and Pesaran tests show evidence of nonstationarity for the twelve panels of countries. For these reasons, also $\ln R P_{i t}$ should be properly considered as I(1). Finally, the time series unit root tests confirm the nonstationarity of world GDP $\left(\ln G D P W_{t}\right)$ as a priori expected.

functions with respect to destination markets, following a substantial within-country approach, but rather the differences with regards to origin exporting economies, thus adopting an across-countries approach.

${ }^{8}$ The null hypothesis is not rejected at the $10 \%$ significance level in the case of Germany. 


\subsection{Panel cointegration tests}

In order to investigate the existence of a long-run relationship between the considered variables, the Pedroni (1999) and Kao (1999) cointegration tests are computed for the 12 panel datasets. Both tests are based on the Engle-Granger (1987) two-stage cointegration test framework. The Pedroni test allows for heterogeneity across crosssections in terms of intercept and trend coefficients. After estimating Equation (1), we test the stationarity of residuals, which will be I(1) under the null hypothesis of no cointegration in a heterogeneous panel. For this purpose, Pedroni $(1999,2000)$ suggests two types of residual-based tests: as for the first type, four tests (panel- $v$, panel- $\rho$, panel$p p$ and panel ADF-statistics) are based on pooling the residuals of the regression along the within-dimension of the panel (panel tests); as for the second type, three tests (group- $\rho$, group- $p p$, and group ADF-statistics) are based on pooling the residuals of the regression along the between-dimension of the panel (group tests). In both cases, the hypothesized cointegrating relationship is estimated separately for each panel member and the resulting residuals are then pooled in order to conduct the panel tests. ${ }^{9}$ In the case where the seven statistics lead to different outcomes, we follow a common practice in the literature (e.g. Bottasso et al., 2013; Lee \& Chang, 2008; Narayan et al., 2007) in assuming that the null hypothesis of no cointegration is rejected if at least four statistics yield evidence of cointegration. Moreover, in our test assessment, we consider that the panel-ADF and group-ADF tests have better small-sample properties than other tests, so that they are more reliable (Pedroni, 1999).

The Kao test follows a similar approach but allows for specific intercepts for each cross-section and homogenous coefficients in the first stage, thus implying heterogeneity in intercepts $\alpha_{i}$ and homogeneity in $\beta_{1 t}$ and $\gamma_{1 i}$ and all coefficient trends to be zero.

\section{Table 4 about here}

Table 4 shows that both the Pedroni and Kao tests reject the null hypothesis of no cointegration in eight out of twelve countries. For the remaining four countries, one test confirms cointegration while the other one does not. In particular, as far as Hong Kong and Turkey are concerned, the Pedroni test cannot reject the null hypothesis of no cointegration but the Kao test does it. On the contrary, in the case of India and Germany, the Pedroni test confirms cointegration, while the Kao test does not. On the whole, since for each country at least one test confirms cointegration, the presence of a long-run relationship between the variables is assumed.

\subsection{Panel Granger causality tests}

Given the existence of a cointegration relationship, the next step is to determine the direction of causality between the variables. In particular, since we are interested in studying price (and income) elasticities, we need to find evidence of a long-run causality from prices (and income) to export volumes. Panel Granger causality is tested

\footnotetext{
${ }^{9}$ For the within dimension, weighted statistics have been calculated as well. They have not been reported in the Tables since they confirm the results of unweighted statistics. Estimates are available upon request.
} 
following the two-step Engle-Granger causality procedure (Engle \& Granger, 1987). First, we apply the panel Mean Group (MG) estimator proposed by Pesaran and Smith (1995) to the previously specified Equation (1). The MG estimator is designed for "moderate-T, moderate-N" macro panels, where moderate typically means about 15 time series/cross-section observations. It is part of the panel time-series (or nonstationary panel) literature, which applies in the presence of unit roots, crosssection dependence and parameter heterogeneity. ${ }^{10,11}$

The second step consists in building a Granger-causality model with a dynamic error correction term (Holtz-Eakin et al., 1998). For this purpose, it is necessary to incorporate the lagged residuals of Equation (1) into the following dynamic error correction model follows:

$$
\begin{aligned}
& \Delta \ln X_{i t}=\alpha_{i}^{X}+\sum_{l=1}^{p} \theta_{i l}^{X} \Delta \ln X_{i, t-l}+\sum_{m=1}^{q} \eta_{i m}^{X} \Delta \ln R P_{i, t-m}+\sum_{n=1}^{r} \mu_{i n}^{X} \Delta \ln G D P W_{t-n}+\omega_{i}^{X} E C T_{i, t-1}+u_{i t} \\
& \Delta \ln R P_{i t}=\alpha_{i}^{R P}+\sum_{l=1}^{p} \theta_{i l}^{R P} \Delta \ln R P_{i, t-l}+\sum_{m=1}^{q} \eta_{i m}^{R P} \Delta \ln X_{i, t-m}+\sum_{n=1}^{r} \mu_{i n}^{R P} \Delta \ln G D P W_{t-n}+\omega_{i}^{R P} E C T_{i, t-1}+v_{i t} \\
& \Delta \ln G D P W_{t}=\alpha_{i}^{G D P W}+\sum_{l=1}^{p} \theta_{i l}^{G D P W} \Delta \ln G D P W_{t-l}+\sum_{m=1}^{q} \eta_{i m}^{G D P W} \Delta \ln X_{i, t-m}+\sum_{n=1}^{r} \mu_{i n}^{G D P W} \Delta \ln R P_{i, t-n}+\omega_{i}^{G D P W} E C T_{i, t-1}+\xi_{i t}
\end{aligned}
$$

where $E C T_{i, t-1}$ is the lagged residual derived from the long-run cointegrating relationship in Equation (1). The parameters $\theta, \eta$ and $\mu$ in Equations (2a), (2b) and (2c) are the short-run adjustment coefficients. $\omega_{i}^{X}, \omega_{i}^{R P}$ and $\omega_{i}^{G D P W}$, instead, indicate how fast deviations from the long-run equilibrium of each variable are eliminated. A high $\omega_{i}$ implies a strong response of any specific variable to a deviation from its longrun equilibrium; on the contrary, a low $\omega_{i}$ implies much more time to go back to equilibrium after a shock. The expected sign of these coefficients is negative, in order to assure convergence toward long-run equilibrium.

The disturbance terms $u_{i t}, v_{i t}$ and $\xi_{i t}$ are uncorrelated and with zero mean. $\Delta$ indicates the first differences of the variables and $p, q$ and $r$ the lag length, usually determined by the Akaike or the Schwarz Information Criteria. In this paper, the Schwarz Information Criterion is used to select the appropriate lag length of the explanatory variables. Our analysis indicates that $p, q$ and $r$ are equal to 1 . Furthermore, given the possible correlation between the lagged variables and the error terms, an instrumental variable estimator is required in order to have an unbiased estimate of Equations (2a), (2b) and (2c).

The estimation method widely applied in comparable studies in different fields of research (Bashiri Behmiri \& Manso, 2012; Costantini \& Martini, 2010; Jaunky, 2012a,b) is the system Generalized Method of Moments (GMM) proposed by Arellano and Bover (1995) and Blundell and Bond (1998). Following Holtz-Eakin et al., (1988),

\footnotetext{
${ }^{10}$ In this paper the MG estimator proposed by Pesaran and Smith is preferred to the more commonly used dynamic OLS (DOLS) or to the fully modified OLS (FMOLS) procedures proposed by Saikkonen (1991) and Pedroni (2000) respectively, since this estimator is more appropriate to our datasets characterized by moderate length $(\mathrm{T}=20)$.

${ }^{11}$ Our estimates are obtained by using the Stata routine proposed by Eberhardt (2012).
} 
Arellano and Bond (1991) developed a GMM estimator that instruments the differenced variables that are not strictly exogenous with all their available lags in levels. Arellano and Bond also developed an appropriate test for autocorrelation, which, if present, can render some lags invalid as instruments. A problem with the original Arellano-Bond estimator is that lagged levels are poor instruments for first-differences if the variables are close to a random walk. Arellano and Bover (1995) describe how, if the original equation in levels is added to the system, additional instruments can be brought to increase efficiency. In this equation, variables in levels are instrumented with suitable lags of their own first-differences. We follow the instructions provided by Roodman (2006, 2009) in order to assess the validity of the instruments and of the instruments subsets, i.e. a high p-value of the Hansen $J$ statistic (of at least 0.25 ) and of the difference-in-Hansen statistic. Furthermore, instruments are collapsed to limit instrument proliferation. ${ }^{12}$ Finally, to control cross-sectional dependence, time dummies are included in the estimates.

In line with the literature, three levels of causality are studied by means of a Wald test: short-run, long-run and strong causality. Considering first Equation (2a), the "short-run Granger causality test" assesses the validity of the null hypothesis $H_{0}: \eta_{i m}^{X}=0$ and $H_{0}: \mu_{i n}^{X}=0$ for all $i, m$ and $n$. The "long-run Granger causality test" checks for the significance of the ECT coefficient; in this case, the null hypothesis is $H_{0}: \omega_{i}^{X}=0$ for all $i$. Finally, strong causality assumes that the null hypotheses $H_{0}: \omega_{i}^{X}=\eta_{i m}^{X}=0$ and $H_{0}: \omega_{i}^{X}=\mu_{i n}^{X}=0$ jointly hold for all cross-sections. Similar null hypotheses are tested for Equations (2b) and (2c).

\section{Table 5 about here}

Table 5 reports the results of the Wald tests on the coefficients. ${ }^{13}$ There is evidence of long-run causality from relative prices and world income to volumes for all countries of the sample. On the contrary, long-run Granger causality from volumes and income to relative prices is verified only for France, Hong Kong and India.

Short-run causality results are rather mixed. Evidence of short-run causality from relative prices to volumes is found for China, France, Germany, Indonesia, Italy, Spain, and the USA. Volumes are found to Granger-cause relative prices in the short run for France, Hong Kong, Spain and UK. World income Granger-causes volumes in the short run in the case of Germany, India and UK while it Granger-causes prices in France, India, Indonesia, Turkey and the USA.

\footnotetext{
${ }^{12}$ More information about our estimations, such as the number of selected instruments in each equation and the usual diagnostic statistics, are available upon request to the authors. However, in line with the literature, the maximum number of instruments used is well below the threshold (maximum number of instruments $=$ N, i.e. 37 in our case) suggested by Roodman $(2006,2009)$.

${ }^{13}$ Since we are interested in the direction of causality between $\ln X_{i t}$ and $\ln R P_{i t}$ (and $\ln G D P W_{t}$ ) in order to understand whether relative prices (and income) determine export volumes or vice versa, we only report the results obtained for Equations (2a) and (2b). Estimates of Equation (2c) were carried out but in general the diagnostic statistics did not allow to draw any conclusions about causality, because of the violations of at least one of the econometric requirements given by Roodman (2006). This result is also in line with a priori economic principles where GDP is an exogenous variable, not dependent on relative prices and export volumes of any specific industrial sector.
} 
Finally, we provide joint Wald $F$-statistics for the interactive terms, i.e. the $E C T$ and the explanatory variables, which give an indication of which variables bear the burden of short-run adjustment to re-establish long-run equilibrium, given a shock to the system (Asafu-Adjaye, 2000). As for Equation (2a), both relative prices and world income are significantly strongly causal in re-adjusting towards equilibrium for all countries. As for Equation (2b), results are mixed for strong causality as well. No evidence of causality is found for China, Germany, Italy, and the USA; both variables are responsible for adjustment in the case of Hong Kong, India and UK; world income is the only significant variable as for France and Turkey; relative prices bear the burden of shortrun adjustment in Indonesia, the Netherlands and Spain.

Then, our analysis confirms that relative prices $\left(\ln R P_{i t}\right)$ and world income $\left(\ln G D P_{t}\right)$ Granger-cause export volumes $\left(\ln X_{i t}\right)$ in the long-run, which is the time horizon we are interested in. Hence we can proceed to compare the estimated long-run price and income elasticities of the selected twelve top exporting countries.

\section{Long-run export elasticities and their stability over time}

\subsection{Long-run export elasticities estimates}

Once the direction of causality from prices and income to export volumes is established, we proceed with the discussion of the estimation results of Equation (1). Our interest is focused on the coefficients $\beta_{1 i}$ and $\gamma_{1 i}$, which indicate the export price and income elasticity for each country. The figures reported in Table 6 are the unweighted averages of the estimated coefficients across groups. All parameters are statistically significant at the $1 \%$ or $5 \%$ confidence level, with the only exceptions price elasticity for Indonesia and income elasticity for the UK.

As regards price elasticities, they appear to be independent of AUVs, market shares or the development stage of a country, i.e. whether it is advanced or emerging. Most country values are within the range $(-0.63,-0.84)$ with the exceptions of the USA, presenting the highest elasticity (-1.23), and Turkey and Spain, showing the lowest (0.36 and -0.41 , respectively).

As regards income elasticities (Table 6), China and Spain present the highest values (2.89 and 3.31 respectively), confirming the high growth rates recorded by their clothing exports during the two decades. India, Turkey, Indonesia, Germany and (slightly) France show an estimated coefficient above 1, which means that their clothing exports grew at a faster rate than world income. The Netherlands and especially Italy show opposite trends. Finally, Hong Kong and the USA exhibit negative income elasticities as a consequence of the big fall in their clothing export volumes. This is, probably due to a shift in their specialization toward more high-tech goods and services as well as their changing role in the global supply chain.

Table 6 about here

The above results could be due to the fact that the MG estimator gives the same weight to all goods independently of their weight in trade volumes. For this reason weighted coefficients for price and income elasticities are computed using as a weight 
the average share of export volume of each good over total clothing exports. The results are shown in Table 7.

Table 7 about here

It is easy to see that the new coefficients are not significantly different from the previous ones, even though China and Hong Kong values move nearer to 1.

\subsection{Stability of export elasticities}

We now move on to investigate the stability of price and income elasticities over the time period considered. Rolling-period elasticities are estimated using Equation (1) and considering 12 different windows, starting from the time span 1992-2000 to 2003-2011 ( $\mathrm{T}=9$ in each of them).

Figures 1 and 2 about here

Our regressions (see Figure 1) indicate that income elasticities are hardly stable in any of the countries. They generally show a decreasing trend, which is particularly marked in India and Indonesia starting from the window 1997-2005 and in the USA from 19952003. With regard to China, the first period considered for estimation is the extended one 1992-2006, since rolling-period price elasticities are not significant until the seventh rolling-window. China's income elasticities, although slightly decreasing, remain above the value of 2.6 in the whole period. An increasing trend is recorded by Germany and the Netherlands. With regard to price elasticities, our results are interesting if related to a partition of the sample countries according to their AUVs. In particular, following a common practice, we use a $15 \%$ relative price difference from average as a yardstick for discrimination. A country is considered to be characterised by low relative-price goods if the majority of AUVs are lower than or equal to 0.85 in the 20 -year period; medium if they lie in the open interval $(0.85-1.15)$; and high if they are equal to or greater than 1.15 .

Figure 2 highlights the existence of a common path for a group of countries where price elasticities start to rise at the end of the 1990s. A closer look reveals that this is the group of medium-price countries, and specifically India, China and Hong Kong, plus the Netherlands. In particular, in the last rolling-windows, price elasticities are higher than $-2,-1.5$ and -1.3 for China, India and Hong Kong respectively, while the long-run elasticities (Table 6) are in line with those of most advanced countries. This supports the hypothesis that these countries' exports, characterised by low/medium AUVs, exhibit a higher price elasticity.

On the other hand, medium/high-price countries show rather stable elasticities below one (in absolute terms), but with differences in their dynamics. They decrease in Germany and the UK and rise in Italy and France. The Spanish elasticity is the lowest for the whole group in the whole period, and Spain is the only country in the medium/high-price group recording a growth in the market share in both volumes and values. This suggests the emergence of a competitive gain as well as an improvement in quality and reputation. Indonesia and Turkey, contrary to a priori expectations, show the rather puzzling feature of having the lowest elasticities in the sample in spite of being low-price countries. Possible explanations, according to the literature, are competence- 
related quality and lead times for Turkey (Neidik \& Gereffi, 2006; Tokatli and Kızılgün, 2009) and cheap but experienced labour force and industrial upgrading of production towards higher value products for Indonesia (Hassler, 2004). However, further investigation of these features would appear to be worthwhile.

Figures 3 and 4 about here

Figures 3 and 4 contribute to a better understanding of the changes in the countries' competitive position over the two decades. Figure 3 plots each country's combination of AUV (horizontal axis) and price elasticity (vertical axis) in the first sub-period 19922000. The size of the circles reflects the market share in volumes for each country. Figure 4 displays the new scenario for the last rolling sub-period 2003-2011. The graphs are divided into four quadrants, partitioned by the mean AUV on the horizontal axis and the mean elasticity on the vertical axis. Obviously, the partition lines change over time; this is particularly relevant for price elasticities, whose mean value doubles in the most recent sub-period. This outcome is mainly due to the behaviour of the elasticities of medium-price countries, and especially China and India.

Germany and France show the highest AUVs in the first sub-period, but rather unexpectedly their export prices decrease in the most recent rolling window. At the same time, their price elasticities fall significantly so that their position shifts from the upper-right to the lower-right quadrant. Italy lies in the quadrant of higher AUVs and more inelastic export demand in both sub-periods; quite interestingly, it is the only country with a significant increase in AUVs. The UK shifts its position from the higher to the lower-right quadrant because of its reduction in price elasticity. A similar trend, although less pronounced, characterizes Spain.

\section{Discussion and conclusions}

In this paper we estimate the price and income elasticities of 12 top exporting countries in the clothing industry for which data are available for the 20 -year period 1992-2011.

First, we check whether the variables of interest in our estimates contain a unit root and are cointegrated. Second, we determine the pattern of causality by means of an Engle-Granger panel procedure. Once verified that relative prices and income Grangercause export volumes for all countries, export function elasticities are estimated by means of a panel data approach. A preliminary analysis reveals that most countries show similar price elasticities, but income elasticities differ considerably. Moreover, looking at the stability of elasticities over time, most countries display unstable coefficients which is especially true for the big Asian exporters in the sample, i.e. China, India and Hong Kong. This confirms the need for caution when using historical estimates to simulate the response of these economies to external shocks.

Analyzing the features and prospects of the clothing industry, various considerations apply to different countries. In particular, China displays the highest price elasticity, which more than triples in the most recent sub-periods, and the second highest income elasticity after Spain. This would appear to indicate a persisting competitive strength of China's clothing exports, but the big increase in price elasticity indicates that small changes in relative prices may have a large impact on the export volumes of the country. 
Hong Kong and India show the same trend, although less pronounced, in price elasticities. Unlike China, this increase is accompanied by a big fall in income elasticities and market share. In the case of India, this is probably the consequence of a structural change of product specialization towards other sectors. In the case of Hong Kong, it is probably because, around the end of the last century, this country lost importance as a production location and became instead a regional trading and sourcing hub, gathering together buyers, sellers and input suppliers (Van Grunsven \& Smakman, 2001).

The USA (Bair \& Gereffi, 2003) and the European countries in the sample (Evans \& Smith, 2006; Gibbon, 2002; Palpacuer, 2006) were also affected by the process of international division of labour whereby production distribution is predominantly organized by firms located in developed countries (Gereffi, 1994). Leading retailers and branders in more advanced countries maintain direct control over design, marketing and retailing activities, and fix product standards for manufacturing suppliers operating in less developed countries (Gereffi, 1999).

This trend is confirmed by the constant decrease in employment and value added in the clothing industry in advanced countries, where a good share of export volumes could be classified as processing trade or re-exports, which are however disregarded by official statistics. This may explain the convergence process between European and Asian AUVs highlighted in Figure 4. Some countries (Germany and Spain) perform better than others (France, the Netherlands and the UK) in their new role of export hubs, when considering price and income elasticities behaviour and market share growth.

Italy appears to be the only advanced European country retaining a strong role for clothing in industrial production, with employment and value added much higher than those for other continental competitors. In 2011, Italy recorded an AUV of 92 USD, which is more than twice that of France, the country with the second highest AUV in the sample. This feature, however, goes along with a big decrease in income elasticity and a rise in price elasticity. There are various possible reasons for the high price of Italian products. On one hand, it could be a sign of a quality-upgrading (Lissovolik, 2008) with a substantial selection process in the clothing industry that leaves only highend firms to survive. On the other hand, it could indicate a loss in competitiveness due to high input costs on the production side, and to a difficult absorption of high-price goods by international markets on the demand side. But, despite the worrying constant decrease in Italy's export share, two elements deserve attention. First, the fact that the country's market share in values, although halved in twenty years, is still high and ranks third after China and Kong Kong. Second, that the demand for Italian goods continues to be inelastic (i.e. with a price elasticity below one in absolute values). There may in fact be an ongoing adjustment process, whereby Italy is positioning in the luxury goods segment, where there is market willingness to pay for high-price high-quality goods.

It is also worth noting, as highlighted in the literature (Berthou \& Emlinger, 2010), that business-cycle recessions are associated with a fall in imports, which can be significantly bigger for high-quality goods, like Italian ones. They are associated with a shift in consumers' preferences towards lower quality. This is a possible explanation for the experience of the last decade, when, under the consequences of a long and deep financial crisis, German and Spanish products, characterized by notably lower unit values, appear to have substituted some Italian goods on international markets. This is consistent with our estimates of the dynamics of export income elasticities, which show a big decrease for Italy in most recent sub-periods. This is partly true also for France 
and the UK, and contrasts with the slight increase recorded by the Netherlands and the still high (although diminishing) values exhibited by Germany and Spain. The income elasticity of exports in fact captures the geographical distribution of destination markets as well as the quality features of goods. A lower income elasticity may also be due to the fact that exports are mainly directed towards slow-growing countries.

In sum, our analysis suggests that advanced countries, including Hong Kong but with the exception of Italy, specialized in the luxury goods segment, have changed their role in the clothing global value chain towards an "organisational" position, whereby industrial production is located elsewhere and the countries become export hubs. Among Asian economies, China confirms its leading position in clothing exports, as also revealed by its very high income elasticity, but its increasing price elasticity sounds a warning with regard to future prospects.

\section{References}

Arellano, M., \& Bond, S. (1991). Some tests of specification for panel data: Monte Carlo evidence and an application to employment equations. Review of Economic Studies, 58, 277-97.

Arellano, M., \& Bover, O. (1995). Another look at the instrumental variables estimation of error components models. Journal of Econometrics, 68, 29-51.

Arize, A.C. (1990). An econometric investigation of export behaviour in seven Asian developing countries. Applied Economics, 22, 891-904.

Arize, A.C. (2001). Traditional Export demand relation and parameter instability. An empirical investigation. Journal of Economic Studies, 28, 378-396.

Asafu-Adjaye, J. (2000). The relationship between energy consumption, energy prices and economic growth: time series evidence from Asian developing countries. Energy Economics, 22, 615-625.

Aziz, J., \& Li, X. (2008). China's changing trade elasticities. China \& World Economy, 16, 1-21.

Bair, J., \& Gereffi. G. (2003). Upgrading, uneven development, and jobs in the North American apparel industry. Global Networks, 3, 143-169.

Bashiri Behmiri, N., \& Pires Manso, J.R. (2012). Crude oil conservation policy hypothesis in OECD (organisation for economic cooperation and development) countries: A multivariate panel Granger causality test. Energy, 43, 253-260.

Berthou A., \& Emlinger, C. (2010). Crises and the collapse of world trade: The shift to lower quality. Working Paper No.7. CEPII, Paris.

Blundell, R., \& Bond, S. (1998). Initial conditions and moment restrictions in dynamic panel data models. Journal of Econometrics, 87, 11-143.

Bottasso, A., Castagnetti, C., Conti, M. (2013). And yet they co-move! Public capital and productivity in OECD. Journal of Policy Modeling, 35, 713-729.

Breitung, J. (2000). The local power of some unit root tests for panel data. In Baltagi B. (Ed.), Nonstationary Panels, Panel Cointegration, and Dynamic Panels, Advances in Econometrics, Vol. 15(pp. 161-178). Amsterdam: JAI.,.

Costantini, V., \& Martini, C. (2010). The causality between energy consumption and economic growth: A multi-sectoral analysis using non-stationary cointegrated panel data. Energy Economics, 32, 591-603. 
Dai M., \& Xu J. (2013), Industry-specific real effective exchange rate for China: 2000-2009. China \& World Economy, 21(5), 100-120.

Eberhardt, M. (2012). Estimating panel time-series models with heterogeneous slopes. The Stata Journal, 12, 61-71.

Engle R.F., \& Granger, C.W.J. (1987). Co-integration and error correction: representation, estimation, and testing. Econometrica, 55, 251-76.

Evans, Y., \& Smith, A. (2006). Surviving at the margins? Deindustrialisation, the creative industries, and upgrading in London's garment sector. Environment \& Planning A, 38(12), 2253-2269.

Gereffi, G. (1994). The organization of buyer-driven global commodity chains: how US retailers shape overseas production networks. In Gereffi, G., Korzeniewicz, M. (Eds.), Commodity Chains and Global Capitalism (pp. 95-122). Westport (CT): Greenwood Press ,.

Gereffi G. (1999). International trade and industrial upgrading in the apparel commodity chain. Journal of International Economics, 48, 37-70.

Gibbon, P. (2002). At the cutting edge? Financialisation and UK clothing retailers' global sourcing patterns and practices. Competition and Change, 6, 289-308.

Hadri, K. (2000). Testing for Stationarity in heterogeneous panel data. Econometrics Journal, 3, 148-161.

Hassler, M. (2004). Changes in the Indonesian clothing industry: Trade and Regulation. Singapore Journal of Tropical Geography, 25(1), 64-76.

Hsiao, F.S.T., \& Hsiao, M.W. (2006). FDI, exports, and GDP in East and Southeast Asia. Panel data versus time-series causality analyses. Journal of Asian Economics, 17, 1082-1106.

Holtz-Eakin D., Newey, W., \& Rosen, H.S. (1988). Estimating vector autoregressions with panel data. Econometrica, 56, 1371-95.

Hooper, P., Johnson K., \& Marquez J. (2000). Trade elasticities for the G-7 countries. Princeton Studies in International Economics, n.87, August.

Jaunky, V.C. (2012a). Is there a material Kuznets curve for aluminium? Evidence from rich countries. Resources Policy, 37, 296-307.

Jaunky, V.C. (2012b). Democracy and economic growth in Sub-Sahara Africa: a panel data approach. Empirical Economics, 45(2), 987-1008.

Kao, C. (1999). Spurious regression and residual-based tests for cointegration in panel data. Journal of Econometrics, 90, 1-44.

Kwiatkowski, D., Phillips, P.C.B., Schmidt, P., \& Shin, Y. (1992). Testing the null of stationarity against the alternative of a unit root: how sure are we the economic time series have a unit root. Journal of Econometrics, 54(1), 159-178.

Lee, C.-C., \& Chang C.-P. (2008). Energy consumption and economic growth in Asian economies: A more comprehensive analysis using panel data. Resource and Energy Economics, 30, 50-65

Lissovolik, B. (2008). Trends in Italy's nonprice competitiveness. IMF Working Paper 124, May.

Lucas, R.F. (1988). Demand for India's manufactured exports. Journal of Development Economics, 29, 63-75.

Mayer, J., (2003). The Fallacy of Composition: a Review of the literature. UNCTAD Discussion Paper 166, February. 
Muscatelli, V.A., Srinivasan, T.G., \& Vines, D. (1992). Demand and Supply Factors in the Determination of NIE Exports: A Simultaneous Error-Correction Model for Hong Kong. The Economic Journal, 102, 1467-1477.

Narayan, P.K., Smyth, R., \& Prasad, A. (2007). Electricity consumption in G7 countries: a panel cointegration analysis of residential demand elasticities. Energy Policy, 35, 4485-4494.

Neidik, B., \& Gereffi, G. (2006). Explaining Turkey's emergence and sustained competitiveness as a full-package supplier of apparel. Environment \& Planning A, 38(12), 2285-2303.

Palpacuer, F., 2006. The global sourcing patterns of French clothing retailers. Environment \& Planning A, 38(12), 2271-2283.

Pedroni, P. (1999). Critical values for cointegration tests in heterogeneous panels with multiple regressors. Oxford Bulletin of Economics and Statistics, 61, 653-670.

Pedroni, P. (2000). Fully modified OLS for the heterogeneous cointegrated panels. Advances in Econometrics, 15, 93-130.

Pesaran, M.H. (2007). A simple panel unit root test in the presence of cross section dependence. Journal of Applied Econometrics, 22, 265-312.

Pesaran, M.H., \& Smith, R.P. (1995). Estimating long-run relationships from dynamic heterogeneous panels. Journal of Econometrics, 68, 79-11.

Roodman, D.M. (2006). How to do xtabond2: an introduction to "difference" and "system" GMM in Stata. Working Paper No. 103. The Center for Global Development, Washington DC.

Roodman, D.M. (2009). A note on the theme of too many instruments. Oxford Bulletin of Economics and Statistics, 71, 135-158.

Said, E., \& Dickey, D.A. (1984). Testing for unit roots in autoregressive moving average models of unknown order. Biometrika, 71, 599-607.

Saikkonen, P. (1991). Asymptotic efficient estimation of cointegration regressions. Econometric Theory, 7, 1-21.

Sharma, K. (2001). Factors determining India's export performance. Journal of Asian Economics, 12, 493-505.

Thorbecke, W., (2010). An empirical analysis of ASEAN's labor-intensive exports. Journal of Asian Economics, 21, 505-513.

Tokatli, N., \& Kızılgün, Ö. (2009). From manufacturing garments for ready-to-wear to designing collections for fast fashion: Evidence from Turkey. Environment and Planning A, 41(1), 146-162.

Yao, Z., Tian, F., \& Su, Q. (2013). Income and price elasticities of China's exports. China \& World Economy, 21, 91-106.

Van Grunsven, L., \& Smakman, F., 2001. Competitive adjustment and advancement in global commodity chains: I. Firm strategies and trajectories in the East Asian apparel industry. Singapore Journal of Tropical Geography, 22(2), 173-188. 


\section{TABLES}

Tab. 1 - Top 15 Clothing exporters: Export values (Billion of USD) and Market shares in 2011

\begin{tabular}{lcc}
\hline & Export value & Market Share \\
\hline China & 153.8 & $37.28 \%$ \\
Hong Kong & 24.5 & $5.94 \%$ \\
Italy & 23.2 & $5.64 \%$ \\
Bangladesh & 19.9 & $4.83 \%$ \\
Germany & 19.6 & $4.76 \%$ \\
India & 14.4 & $3.48 \%$ \\
Turkey & 13.9 & $3.38 \%$ \\
Vietnam & 13.2 & $3.19 \%$ \\
France & 11.0 & $2.67 \%$ \\
Spain & 9.2 & $2.24 \%$ \\
Belgium & 9.0 & $2.20 \%$ \\
Netherlands & 8.2 & $2.00 \%$ \\
Indonesia & 8.0 & $1.95 \%$ \\
United Kingdom & 6.6 & $1.59 \%$ \\
United States & 5.2 & $1.27 \%$ \\
Total & 340.0 & $82.42 \%$ \\
\hline \multicolumn{2}{l}{ Source: our elaboration on WTO data }
\end{tabular}


Tab. 2 - Descriptive statistics: Export volumes, Market shares and Average unit values, Beginning-of-period, End-of-period and Average-of-period

\begin{tabular}{|c|c|c|c|c|c|c|c|c|c|}
\hline & \multicolumn{3}{|c|}{ Export volumes (tons) } & \multicolumn{3}{|c|}{ Market shares (\% of export volumes) } & \multicolumn{3}{|c|}{ Average unit values (USD) } \\
\hline & 1992 & 2011 & Average & 1992 & 2011 & Average & 1992 & 2011 & Average \\
\hline China & 766,578 & $4,411,045$ & $2,401,827$ & 24.67 & 52.43 & 37.39 & 21.79 & 34.86 & 24.10 \\
\hline France & 94,758 & 241,942 & 161,746 & 3.05 & 2.88 & 2.70 & 55.58 & 45.64 & 46.05 \\
\hline Germany & 158,99 & 476,753 & 260,227 & 5.12 & 5.67 & 4.22 & 52.54 & 42.13 & 43.79 \\
\hline Hong Kong & 836,787 & 600,745 & 881,465 & 26.93 & 7.14 & 16.60 & 23.97 & 40.79 & 27.96 \\
\hline India & 119,73 & 494,487 & 257,506 & 3.85 & 5.88 & 4,27 & 25.97 & 29.63 & 26.48 \\
\hline Indonesia & 193,199 & 504,879 & 358,149 & 6.22 & 6.00 & 6.07 & 16.38 & 15.93 & 12.99 \\
\hline Italy & 238,211 & 251,866 & 293,345 & 7.67 & 2.99 & 5.42 & 51.40 & 92.31 & 58.15 \\
\hline Netherlands & 83,144 & 212,011 & 137,225 & 2.68 & 2.52 & 2.93 & 32.51 & 41.20 & 28.43 \\
\hline Spain & 23,194 & 213,99 & 94,751 & 0.75 & 2.54 & 1.45 & 30.53 & 42.85 & 35.91 \\
\hline Turkey & 182,137 & 537,145 & 425,891 & 5.86 & 6.38 & 7.17 & 22.95 & 25.97 & 20.73 \\
\hline UK & 112,924 & 194,793 & 160,879 & 3.63 & 2.32 & 2.91 & 32.40 & 34.04 & 29.42 \\
\hline USA & 298,117 & 273,195 & 494,719 & 9.59 & 3.25 & 9.49 & 14.13 & 19.12 & 13.00 \\
\hline
\end{tabular}


Tab. 3a - Panel Unit Root Test Statistics for the variable $\ln X_{i}$

\begin{tabular}{lcccc}
\hline & Breitung & Hadri & Pesaran without trend & Pesaran with trend \\
\hline China & $6.74(0.88)$ & $63.89(0.00)$ & $-0.70(0.24)$ & $0.40(0.65)$ \\
France & $2.21(0.99)$ & $53.86(0.00)$ & $0.77(0.78)$ & $3.3210(1.00)$ \\
Germany & $4.86(1.00)$ & $62.48(0.00)$ & $0.01(0.50)$ & $0.99(0.84)$ \\
Hong kong & $1.39(0.91)$ & $49.09(0.00)$ & $3.69(1.00)$ & $0.89(0.81)$ \\
India & $2.85(0.99)$ & $42.19(0.00)$ & $-0.91(0.18)$ & $-0.92(0.18)$ \\
Indonesia & $-0.14(0.44)$ & $49.50(0.00)$ & $-0.54(0.29)$ & $0.34(0.64)$ \\
Italy & $0.24(0.59)$ & $36.43(0.00)$ & $2.90(0.99)$ & $3.08(0.99)$ \\
Netherlands & $1.02(0.85)$ & $43.12(0.00)$ & $0.07(0.53)$ & $0.41(0.66)$ \\
Spain & $7.62(1.00)$ & $63.24(0.00)$ & $-0.39(0.35)$ & $1.54(0.94)$ \\
Turkey & $3.62(0.99)$ & $43.72(0.00)$ & $0.69(0.75)$ & $2.71(0.99)$ \\
UK & $-2.54(0.00)$ & $32.47(0.00)$ & $-0.72(0.24)$ & $-0.42(0.34)$ \\
USA & $-1.08(0.14)$ & $42.52(0.00)$ & $1.04(0.85)$ & $1.98(0.97)$ \\
\hline
\end{tabular}

Notes: The lambda-statistics, z-statistics and the standardized Zt-bars are reported for the Breitung (2000), Hadri (2000) and Pesaran (2007) unit root tests, respectively; p-values in parentheses; the Breitung and Hadri tests are calculated by including the intercept in the test equations, while the Pesaran test is computed by adding also a time trend; the null hypothesis for all tests is "Panels contain unit roots" with the exception of the Hadri test, whose null hypothesis is "All panels are stationary".

Tab. 3b- Panel Unit Root Test Statistics for the variable $\ln R P_{i}$

\begin{tabular}{|c|c|c|c|c|}
\hline & Breitung & Hadri & Pesaran without trend & Pesaran with trend \\
\hline China & $1.21(0.89)$ & $31.93(0.00)$ & $-0.87(0.19)$ & $-0.58(0.28)$ \\
\hline France & $-2.61(0.00)$ & $36.35(0.00)$ & $-0.11(0.46)$ & $-0.58(0.28)$ \\
\hline Germany & $-1.52(0.06)$ & $47.39(0.00)$ & $-0.24(0.41)$ & $-0.41(0.34)$ \\
\hline Hong kong & $-1.74(0.04)$ & $38.05(0.00)$ & $-0.36(0.36)$ & $-1.17(0.12)$ \\
\hline India & $-3.34(0.00)$ & $36.02(0.00)$ & $0.86(0.80)$ & $1.62(0.95)$ \\
\hline Indonesia & $-0.01(0.49)$ & $44.34(0.00)$ & $0.47(0.68)$ & $0.69(0.76)$ \\
\hline Italy & $-5.10(0.00)$ & $23.72(0.00)$ & $-0.31(0.38)$ & $0.16(0.56)$ \\
\hline Netherlands & $-3.81(0.00)$ & $38.09(0.00)$ & $-0.82(0.20)$ & $-0.84(0.20)$ \\
\hline Spain & $-3.20(0.00)$ & $31.21(0.00)$ & $1.83(0.97)$ & $3.43(1.00)$ \\
\hline Turkey & $-3.23(0.00)$ & $20.92(0.00)$ & $-0.25(0.40)$ & $0.19(0.58)$ \\
\hline $\mathrm{UK}$ & $-6.49(0.00)$ & $21.43(0.00)$ & $-1.03(0.15)$ & $-0.34(0.37)$ \\
\hline USA & $-3.51(0.00)$ & $30.58(0.00)$ & $-1.22(0.11)$ & $-0.07(0.47)$ \\
\hline
\end{tabular}

Note: See Table $3 a$. 
Tab. 3c - Unit Root Tests for the variable InGDPW $_{t}$

\begin{tabular}{cc}
\hline ADF & KPSS \\
\hline 0.34 & 0.61 \\
$(0.97)$ & {$[0.46]$} \\
\hline
\end{tabular}

Notes: The t-statistics and $L M$-statistics are reported for the Augmented Dickey-Fuller (ADF) and the Kwiatkowski-Phillips-Schmidt-Shin (KPSS) unit root tests; pvalues and asymptotic critical values in parentheses and brackets, respectively; an asymptotic critical value of 0.46 corresponds to the 5\% significance level; the ADF and the KPSS unit root tests are calculated by including the intercept in the test equations; the null hypothesis is "InGDPW has a unit root" for the ADF test and "InGDPW $W_{t}$ is stationary" for the KPSS test.

Tab. 4 - Pedroni and Kao Panel Cointegration Tests

\begin{tabular}{|c|c|c|c|c|c|c|c|c|c|c|c|c|}
\hline & China & France & Germany & Hong Kong & India & Indonesia & Italy & Netherlands & Spain & Turkey & UK & USA \\
\hline \multicolumn{13}{|l|}{ Pedroni test } \\
\hline Panel $v$-Statistic & $\begin{array}{c}-225.52 \\
(1.00)\end{array}$ & $\begin{array}{c}-292.31 \\
(1.00)\end{array}$ & $\begin{array}{c}-170.15 \\
(1.00)\end{array}$ & $\begin{array}{c}-233.59 \\
(1.00)\end{array}$ & $\begin{array}{c}-111.33 \\
(1.00)\end{array}$ & $\begin{array}{r}-74.01 \\
(1.00)\end{array}$ & $\begin{array}{c}-265.07 \\
(1.00)\end{array}$ & $\begin{array}{c}0.66 \\
(0.25)\end{array}$ & $\begin{array}{c}-40.92 \\
(1.00)\end{array}$ & $\begin{array}{l}-59.81 \\
(1.00)\end{array}$ & $\begin{array}{c}-368.05 \\
(1.00)\end{array}$ & $\begin{array}{c}-273.09 \\
(0.06)\end{array}$ \\
\hline Panel $\rho$-Statistic & $\begin{array}{c}-1.08 \\
(0.14)\end{array}$ & $\begin{array}{c}-0.68 \\
(0.25)\end{array}$ & $\begin{array}{c}-1.33 \\
(0.09)\end{array}$ & $\begin{array}{c}0.00 \\
(0.50)\end{array}$ & $\begin{array}{c}-0.11 \\
(0.46)\end{array}$ & $\begin{array}{c}-0.67 \\
(0.25)\end{array}$ & $\begin{array}{c}-1.04 \\
(0.15)\end{array}$ & $\begin{array}{l}-0.46 \\
(0.32)\end{array}$ & $\begin{array}{c}0.16 \\
(0.56)\end{array}$ & $\begin{array}{c}0.45 \\
(0.67)\end{array}$ & $\begin{array}{c}-0.29 \\
(0.39)\end{array}$ & $\begin{array}{l}-1.69 \\
(0.04)\end{array}$ \\
\hline Panel pp-Statistic & $\begin{array}{l}-2.92 \\
(0.00)\end{array}$ & $\begin{array}{l}-2.66 \\
(0.00)\end{array}$ & $\begin{array}{c}-2.094 \\
(0.02)\end{array}$ & $\begin{array}{l}-1.51 \\
(0.06)\end{array}$ & $\begin{array}{l}-1.62 \\
(0.05)\end{array}$ & $\begin{array}{l}-2.97 \\
(0.00)\end{array}$ & $\begin{array}{l}-4.15 \\
(0.00)\end{array}$ & $\begin{array}{l}-2.26 \\
(0.01)\end{array}$ & $\begin{array}{l}-2.45 \\
(0.00)\end{array}$ & $\begin{array}{l}-1.35 \\
(0.09)\end{array}$ & $\begin{array}{l}-2.03 \\
(0.02)\end{array}$ & $\begin{array}{l}-6.68 \\
(0.00)\end{array}$ \\
\hline Panel adf-Statistic & $\begin{array}{l}-4.96 \\
(0.00)\end{array}$ & $\begin{array}{l}-4.94 \\
(0.00)\end{array}$ & $\begin{array}{l}-1.55 \\
(0.06)\end{array}$ & $\begin{array}{l}-4.80 \\
(0.00)\end{array}$ & $\begin{array}{l}-2.30 \\
(0.01)\end{array}$ & $\begin{array}{l}-4.85 \\
(0.00)\end{array}$ & $\begin{array}{l}-3.36 \\
(0.00)\end{array}$ & $\begin{array}{l}-1.75 \\
(0.04)\end{array}$ & $\begin{array}{l}-2.84 \\
(0.00)\end{array}$ & $\begin{array}{l}-1.52 \\
(0.06)\end{array}$ & $\begin{array}{l}-3.75 \\
(0.00)\end{array}$ & $\begin{array}{l}-3.81 \\
(0.00)\end{array}$ \\
\hline Group $\rho$-Statistic & $\begin{array}{c}0.69 \\
(0.75)\end{array}$ & $\begin{array}{c}1.59 \\
(0.94)\end{array}$ & $\begin{array}{l}-1.23 \\
(0.11)\end{array}$ & $\begin{array}{c}2.21 \\
(0.98)\end{array}$ & $\begin{array}{c}1.24 \\
(0.89)\end{array}$ & $\begin{array}{c}1.58 \\
(0.94)\end{array}$ & $\begin{array}{c}0.62 \\
(0.73)\end{array}$ & $\begin{array}{c}1.32 \\
(0.91)\end{array}$ & $\begin{array}{c}1.48 \\
(0.93)\end{array}$ & $\begin{array}{c}2.55 \\
(0.99)\end{array}$ & $\begin{array}{c}0.49 \\
(0.69)\end{array}$ & $\begin{array}{c}0.18 \\
(0.57)\end{array}$ \\
\hline Group pp-Statistic & $\begin{array}{l}-2.69 \\
(0.00)\end{array}$ & $\begin{array}{c}-3.18 \\
(0.00)\end{array}$ & $\begin{array}{l}-6.59 \\
(0.00)\end{array}$ & $\begin{array}{l}-0.78 \\
(0.22)\end{array}$ & $\begin{array}{l}-2.06 \\
(0.02)\end{array}$ & $\begin{array}{l}-3.31 \\
(0.00)\end{array}$ & $\begin{array}{l}-4.08 \\
(0.00)\end{array}$ & $\begin{array}{l}-2.68 \\
(0.00)\end{array}$ & $\begin{array}{l}-2.54 \\
(0.00)\end{array}$ & $\begin{array}{l}-0.73 \\
(0.23)\end{array}$ & $\begin{array}{l}-3.31 \\
(0.00)\end{array}$ & $\begin{array}{l}-6.89 \\
(0.00)\end{array}$ \\
\hline $\begin{array}{l}\text { Group adf- } \\
\text { Statistic }\end{array}$ & $\begin{array}{l}-6.08 \\
(0.00)\end{array}$ & $\begin{array}{l}-6.89 \\
(0.00)\end{array}$ & $\begin{array}{l}-6.07 \\
(0.00)\end{array}$ & $\begin{array}{l}-4.47 \\
(0.00)\end{array}$ & $\begin{array}{l}-2.86 \\
(0.00)\end{array}$ & $\begin{array}{l}-3.98 \\
(0.00)\end{array}$ & $\begin{array}{l}-4.29 \\
(0.00)\end{array}$ & $\begin{array}{l}-2.04 \\
(0.02)\end{array}$ & $\begin{array}{l}-3.96 \\
(0.00)\end{array}$ & $\begin{array}{l}-1.64 \\
(0.04)\end{array}$ & $\begin{array}{l}-5.48 \\
(0.00)\end{array}$ & $\begin{array}{l}-3.31 \\
(0.00)\end{array}$ \\
\hline
\end{tabular}




\section{Kao test}

$\mathrm{ADF}$

$-4.11$ $(0.00)$

$-1.03$

$-1.77^{\star}$

$-1.09^{*}$

$-2.36$

(0.00)

$-1.44^{\star}$

$-3.21$

$(0.07)$

$(0.00)$

$-3.35$

$(0.00)$

$-5.43$

$-3.72$

(0.00)

$-3.82$ values in parentheses; the lag length selection is based on SIC unless specified by adding a ${ }^{*}$ which indicates a User-specified lag length equal to 1 ; trend and intercept options are: "No deterministic trend" for all countries with the exception of the Netherlands, Spain and Turkey for which the option used was "No deterministic intercept or trend". 
Tab. 5 - Panel Granger causality tests

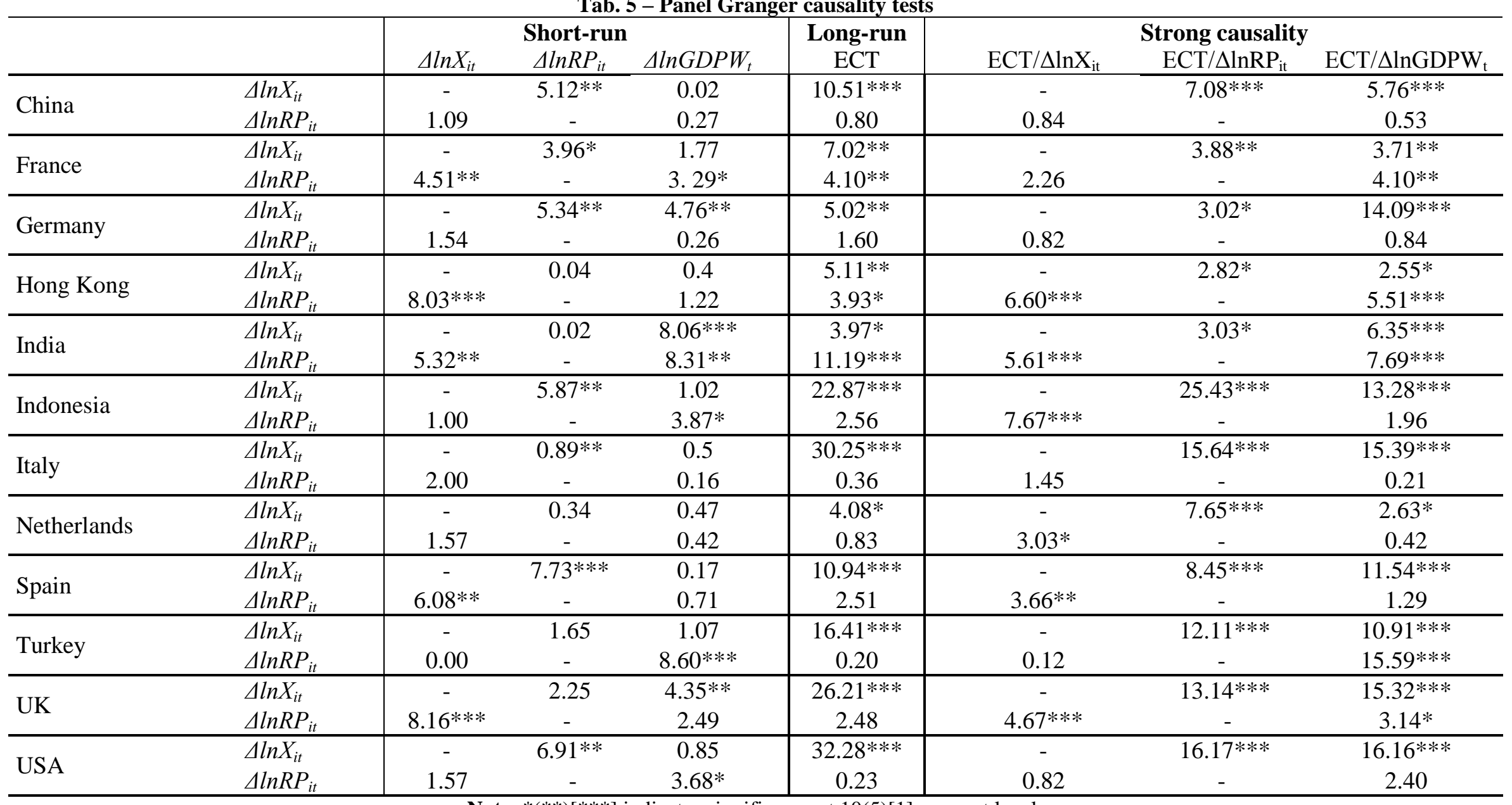

Note: $*(* *)[* * *]$ indicates significance at $10(5)[1]$ per cent level. 
Tab. 6 - Long-run estimates of Equation (1)

\begin{tabular}{|c|c|c|c|c|c|c|c|c|c|c|c|c|}
\hline & China & France & Germany & Hong Kong & India & Indonesia & Italy & Netherlands & Spain & Turkey & UK & USA \\
\hline $\ln R P_{i t}$ & $\begin{array}{c}-0.83 * * * \\
(0.17)\end{array}$ & $\begin{array}{c}-0.66 * * * \\
(0.08)\end{array}$ & $\begin{array}{c}-0.71 * * * \\
(0.08)\end{array}$ & $\begin{array}{c}-0.84 * * * \\
(0.17)\end{array}$ & $\begin{array}{c}-0.63 * * * \\
(0.14)\end{array}$ & $\begin{array}{c}-0.17 \\
(0.10)\end{array}$ & $\begin{array}{c}-0.76 * * * \\
(0.12)\end{array}$ & $\begin{array}{c}-0.79 * * * \\
(0.11)\end{array}$ & $\begin{array}{c}-0.41 * * * \\
(0.13)\end{array}$ & $\begin{array}{c}-0.36 * * \\
(0.15)\end{array}$ & $\begin{array}{c}-0.85 * * * \\
(0.07)\end{array}$ & $\begin{array}{c}-1.23 * * * \\
(0.18)\end{array}$ \\
\hline $\ln G D P W_{t}$ & $\begin{array}{c}2.87 * * * \\
(0.28)\end{array}$ & $\begin{array}{c}1.06 * * * \\
(0.17)\end{array}$ & $\begin{array}{c}1.33 * * * \\
(0.25)\end{array}$ & $\begin{array}{c}-0.60 * * \\
(0.27)\end{array}$ & $\begin{array}{c}1.71 * * * \\
(0.25)\end{array}$ & $\begin{array}{c}1.41 * * * \\
(0.25)\end{array}$ & $\begin{array}{c}0.65 * * * \\
(0.15)\end{array}$ & $\begin{array}{c}0.93 * * * \\
(0.25)\end{array}$ & $\begin{array}{c}3.31 * * * \\
(0.32)\end{array}$ & $\begin{array}{c}1.52 * * * \\
(0.25)\end{array}$ & $\begin{array}{c}0.21 \\
(0.16)\end{array}$ & $\begin{array}{c}-1.26 * * * \\
(0.31)\end{array}$ \\
\hline Constant & $\begin{array}{c}-13.16 * * * \\
(3.02)\end{array}$ & $\begin{array}{l}3.83 * * \\
(1.76)\end{array}$ & $\begin{array}{c}1.30 \\
(2.63)\end{array}$ & $\begin{array}{c}22.67 * * * \\
(2.86)\end{array}$ & $\begin{array}{l}-3.53 \\
(2.69)\end{array}$ & $\begin{array}{c}0.29 \\
(2.72)\end{array}$ & $\begin{array}{c}8.89 * * * \\
(1.64)\end{array}$ & $\begin{array}{l}-4.69 * \\
(2.65)\end{array}$ & $\begin{array}{c}-20.96 * * * \\
(3.37)\end{array}$ & $\begin{array}{l}-0.99 \\
(2.74)\end{array}$ & $\begin{array}{c}12.71 * * * \\
(1.70)\end{array}$ & $\begin{array}{c}28.18 * * * \\
(3.28)\end{array}$ \\
\hline
\end{tabular}

Note: Standard errors in parentheses; ***)[***] indicates significance at 10(5)[1] per cent level.

Tab. 7 - Long-run weighted estimates of Equation (1)

\begin{tabular}{|c|c|c|c|c|c|c|c|c|c|c|c|c|}
\hline & China & France & Germany & Hong Kong & India & Indonesia & Italy & Netherlands & Spain & Turkey & UK & USA \\
\hline $\ln R P_{i t}$ & $\begin{array}{c}-0.92 * * * \\
(0.16)\end{array}$ & $\begin{array}{c}-0.73 * * * \\
(0.09)\end{array}$ & $\begin{array}{c}-0.75 * * * \\
(0.08)\end{array}$ & $\begin{array}{c}-0.96 * * * \\
(0.13)\end{array}$ & $\begin{array}{c}-0.62 * * * \\
(0.14)\end{array}$ & $\begin{array}{c}-0.14 \\
(0.11)\end{array}$ & $\begin{array}{c}-0.74 * * * \\
(0.12)\end{array}$ & $\begin{array}{c}-0.72 * * * \\
(0.13)\end{array}$ & $\begin{array}{c}-0.43^{* * *} * \\
(0.14)\end{array}$ & $\begin{array}{c}-0.39 * * \\
(0.15)\end{array}$ & $\begin{array}{c}-0.87 * * * \\
(0.05)\end{array}$ & $\begin{array}{c}-1.25 * * * \\
(0.18)\end{array}$ \\
\hline $\ln G D P W_{t}$ & $\begin{array}{c}2.69 * * * \\
(0.30)\end{array}$ & $\begin{array}{c}0.91 * * * \\
(0.17)\end{array}$ & $\begin{array}{c}1.24 * * * \\
(0.27)\end{array}$ & $\begin{array}{c}-0.50 * \\
(0.27)\end{array}$ & $\begin{array}{c}1.68 * * * \\
(0.25)\end{array}$ & $\begin{array}{c}1.36 * * * \\
(0.24)\end{array}$ & $\begin{array}{c}0.64 * * * \\
(0.15)\end{array}$ & $\begin{array}{c}0.86 * * * \\
(0.27)\end{array}$ & $\begin{array}{c}3.48 * * * \\
(0.34)\end{array}$ & $\begin{array}{c}1.53 * * * \\
(0.25)\end{array}$ & $\begin{array}{c}0.06 \\
(0.15)\end{array}$ & $\begin{array}{c}-1.32 * * * \\
(0.31)\end{array}$ \\
\hline
\end{tabular}




\section{FIGURES}

Figure 1 - Income elasticities estimated from rolling equations

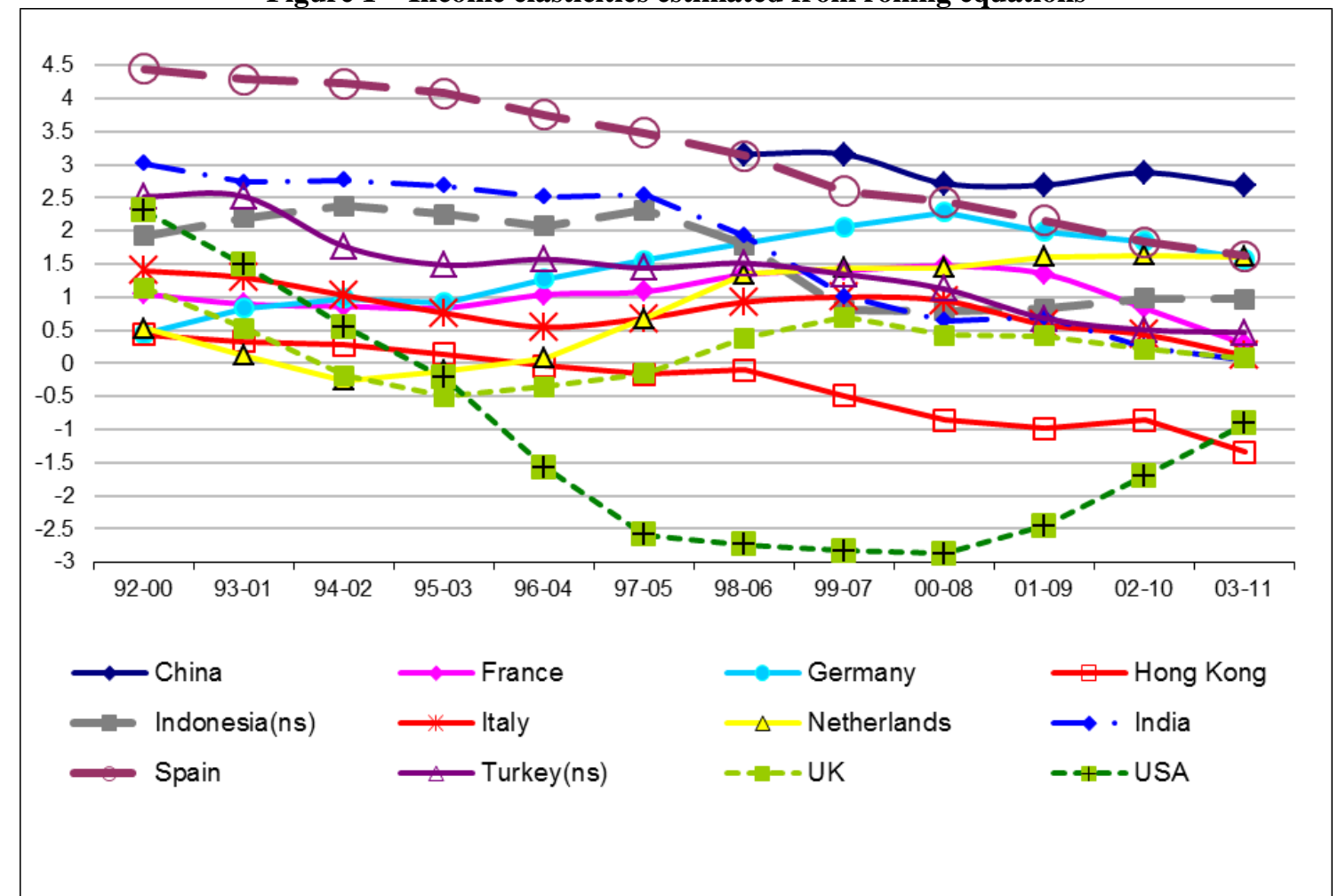

Notes: With regard to China, the first period considered for estimation is the extended one 1992-2006 since rolling-period price elasticities are not significant until the $7^{\text {th }}$ period. 
Figure 2 - Price elasticities estimated from rolling equations

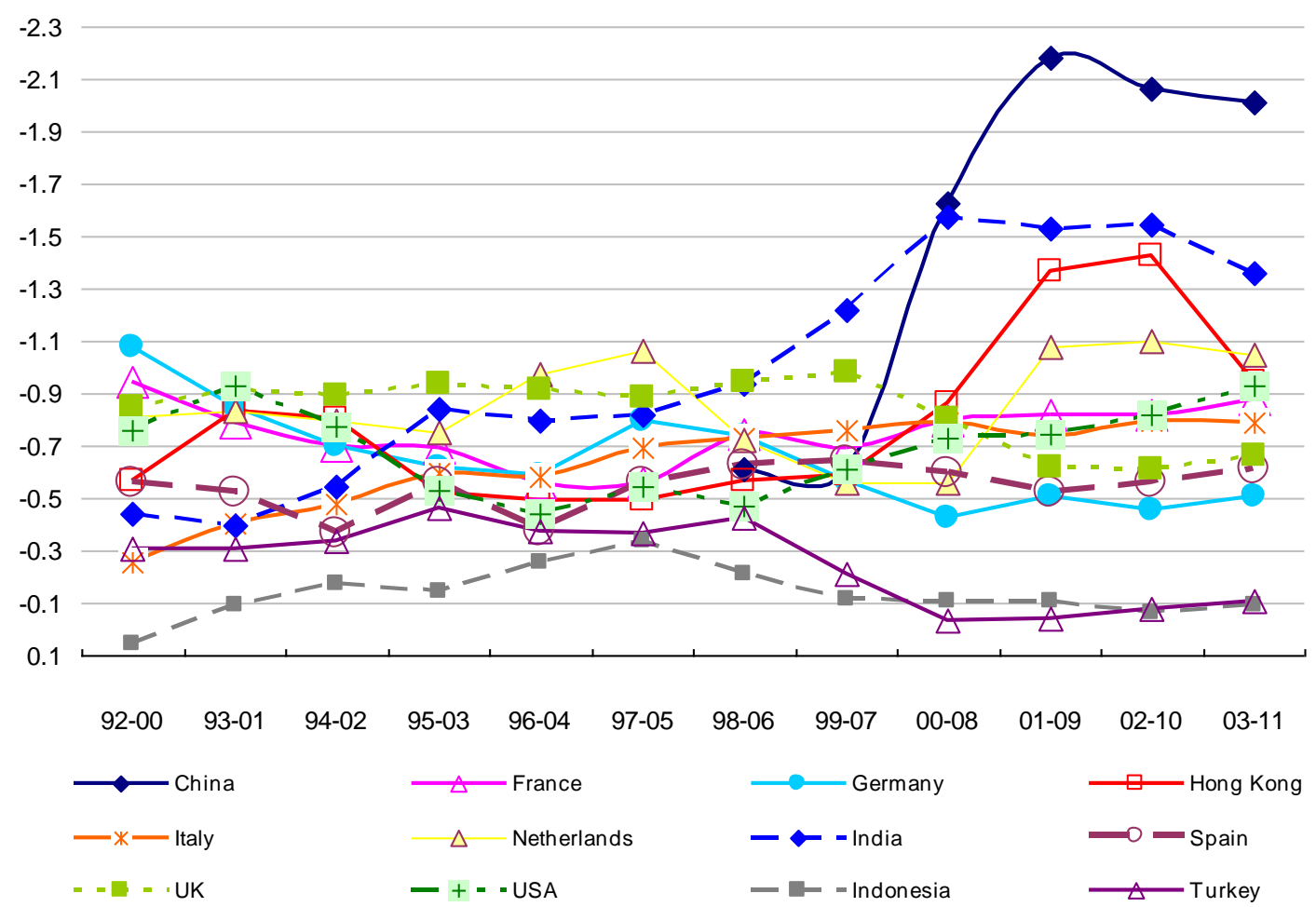

Notes: With regard to China, the first period considered for estimation is the extended one 1992-2006 since rolling-period price elasticities are not significant until the $7^{\text {th }}$ period. 
Figure 3 - Positioning of the various countries in terms of AUVs and price elasticities; time period 1992- 2000

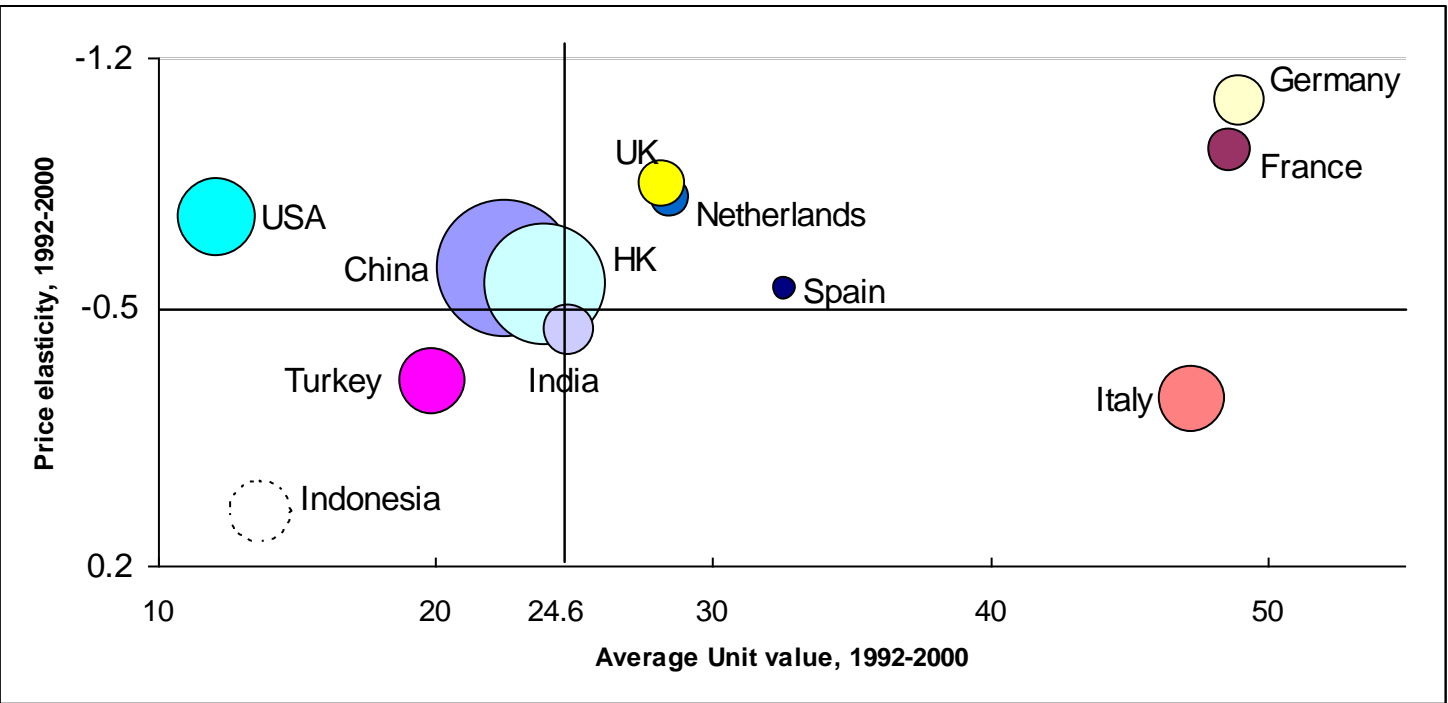

Notes: Price elasticities are estimated for the rolling period 1992-2000. The size of the circles is given by the average market share in volumes for the same period. In order to obtain a significant price elasticity, for China the considered sub-period is 1992-2006. The price elasticity for Indonesia is not significant for any sub-period.

Figure 4 - Positioning of the various countries in terms of AUVs and price elasticities; time period 2003-2011

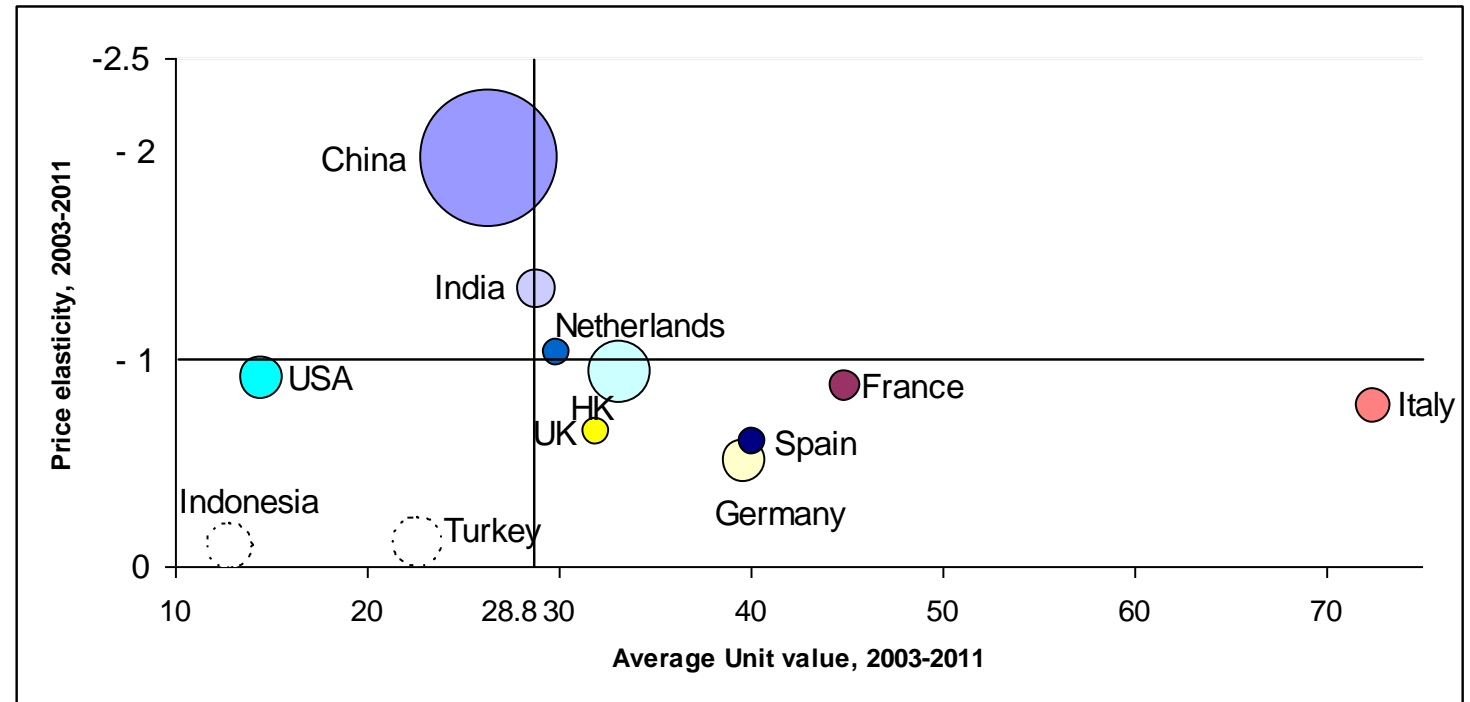

Notes: Price elasticities are estimated for the rolling period 2003-2011. The size of the circles is given by the average market share in volumes for the same period. The price elasticities for Indonesia and Turkey are not significant in the sub-period considered. 


\section{APPENDIX}

Tab. A1 - Shares of clothing exports on total commodities exports, World and selected countries, Beginning-of-period and End-of-period percentages

\begin{tabular}{|c|c|c|c|c|c|c|c|c|c|c|c|c|c|}
\hline & World & China & France & Germany & Hong Kong & India & Indonesia & Italy & Netherlands & Spain & Turkey & UK & USA \\
\hline 1992 & 3.68 & 19.67 & 2.27 & 1.94 & 16.77 & 15.02 & 9.32 & 6.86 & 1.93 & 1.10 & 28.40 & 1.92 & 0.94 \\
\hline 2011 & 2.34 & 8.10 & 1.90 & 1.36 & 5.38 & 4.86 & 3.95 & 4.44 & 1.65 & 3.07 & 10.34 & 1.40 & 0.35 \\
\hline
\end{tabular}

Source: our elaboration on WTO data 
Tab. A2 -Clothing goods, SITC Classification Rev. 3

\begin{tabular}{|c|c|c|}
\hline \multicolumn{2}{|c|}{ Commodity Code } & Commodity Description \\
\hline \multicolumn{3}{|c|}{84 CLOTHING AND ACCESSORIES } \\
\hline \multirow[t]{7}{*}{841} & \multicolumn{2}{|c|}{ MEN, BOYS CLOTHING, NOT KNITTED } \\
\hline & 8411 & Overcoats, outerwear, etc. \\
\hline & 8412 & Suits and ensembles \\
\hline & 8413 & Jackets and blazers, men's or boys', of textile materials, not knitted or crocheted \\
\hline & 8414 & Trousers, bib and brace overalls, breeches and shorts, men's or boys' \\
\hline & 8415 & Shirts \\
\hline & 8416 & Underwear, nightwear, etc. \\
\hline \multirow[t]{9}{*}{842} & \multicolumn{2}{|c|}{ WOMEN, GIRLS CLOTHING, NOT KNITTED } \\
\hline & 8421 & Overcoats, other coats, etc. \\
\hline & 8422 & Suits and ensembles \\
\hline & 8423 & Jackets and blazers, women's or girls', of textile materials, not knitted \\
\hline & 8424 & Dresses, women's or girls', of textile materials, not knitted or crocheted \\
\hline & 8425 & Skirts and divided skirts, women's or girls', of textile materials, not knitted \\
\hline & 8426 & Trousers, bib and brace overalls, breeches and shorts, women's or girls' \\
\hline & 8427 & Blouses, shirts \\
\hline & 8428 & Underwear, nightwear, etc. \\
\hline \multirow[t]{5}{*}{843} & MEN, B & CLOTHING, KNITTED \\
\hline & 8431 & Overcoats, car coats, capes, cloaks, anoraks (including ski jackets) \\
\hline & 8432 & Suits, jackets, trousers, etc. \\
\hline & 8437 & Shirts, knitted \\
\hline & 8438 & Underwear, nightwear, etc. \\
\hline \multirow[t]{5}{*}{844} & WOME & RLS CLOTHING, KNITTED \\
\hline & 8441 & Overcoats, car coats, capes, cloaks, anoraks (including ski jackets) \\
\hline & 8442 & Suits, dresses skirts, etc. \\
\hline & 8447 & Blouses, shirts and shirt blouses, women's or girls', knitted or crocheted \\
\hline & 8448 & Underwear, nightwear, etc. \\
\hline \multirow[t]{9}{*}{845} & \multicolumn{2}{|c|}{ OTHER TEXTILE APPAREL, NES } \\
\hline & 8451 & Babies' garments, clothes, accessories \\
\hline & 8452 & Garment, felt, textile fabric \\
\hline & 8453 & Jerseys, pullovers, cardigans, waistcoats and similar articles, knitted \\
\hline & 8454 & Tshirts, singlets and other vests, knitted or crocheted \\
\hline & 8455 & Brassieres, corsets, etc. \\
\hline & 8456 & Swimwear \\
\hline & 8458 & Other garments, not knitted \\
\hline & 8459 & Other garments, knitted \\
\hline \multirow[t]{4}{*}{846} & CLOTH & ACCESSORIES, FABRIC \\
\hline & 8461 & Accessories, not knitted \\
\hline & 8462 & Hosiery, etc. knitted \\
\hline & 8469 & Other madeup clothing accessories \\
\hline \multirow[t]{5}{*}{848} & CLOTH & NONTEXTILE; HEADGEAR \\
\hline & 8481 & Leather apparel, accessories \\
\hline & 8482 & Plastic, rubber apparel, etc. \\
\hline & 8483 & Articles, accessories fur \\
\hline & 8484 & Headgear, fittings, nes \\
\hline
\end{tabular}

Note: Only 4-digit level goods are used in the empirical analysis; the whole list is provided for completeness 